\title{
Mishima Yukio and the Homoeroticisation of the Emperor of Japan
}

\author{
Kazuyoshi Kawasaka ${ }^{1 *}$
}

Published: September 27, 2018

\begin{abstract}
This article aims to contextualise Mishima Yukio's works and nationalist politics into a history of Japanese queer politics. Mishima Yukio is considered as one of the most prominent artists in modern Japan, famous for his homosexual-themed works and nationalist politics. This article explores the discursive relationships between Japanese national politics and homoeroticism through analysing Mishima Yukio's works. It will review discourses about Mishima, his performance, works and sexuality; it points out how these discourses contain homophobic presumptions and overlook the wider social and historical contexts of Mishima's works. The article will discuss Mishima's far-right political discourses and representations in his famous political essays The Defense of Culture (Bunka böuei ron) (1969) and The Manifesto of Anti-revolution (Han-kakumei ron) (1969) and the film Patriot (Yükoku) (1966). This article points out that Mishima intertwined homoerotic ethos and Japanese national politics through the emperor, establishing a space for queer homoerotic desire in Japan's public culture and politics. In conclusion, this article discusses how Mishima's representation of the homoeroticised emperor prepared the ground to limit political discourses of queer politics in contemporary Japan.
\end{abstract}

Keywords: Mishima Yukio, homosexuality in Japan, gay politics, the emperor system, queer in Japan

\section{INTRODUCTION}

Mishima Yukio (1925-1970) was a distinctive artist and popular figure in post-war Japan, bringing homoeroticism to national culture. Mishima is not only one of the most popular writers in post-war Japan, but he is also considered as an artist who was the successor to traditional Japanese culture (Keen, 2006). Even though more than forty years have passed since his scandalous death, his novels, photographs and academic books about him, have been published constantly in Japan.

Mishima remains influential as an ideologue of far-right politics in Japan. He often represented himself in public as a traditional Japanese man, or 'samurai' warrior who is a protector of the emperor (Mishima, 2006b). He wrote several stories and political essays for nationalistic causes in Japan and passionately engaged in right-wing politics. His followers, who frequently admire his far-right political beliefs, have organised events, called Yükoku-ki, which means the 'anniversary of patriot's death', every year. His performances, acting the 'samurai' in post-war Japan, are well-remembered among the Japanese. His most iconic performance was when he appeared with his self-designed militant uniform at the Tokyo headquarters of the Eastern Command of the Japan Self-Defense Forces in 25 November 1970 and addressed officers involved in his attempted coup d'état to revoke Japan's pacifist Constitution and re-militarise Japan with the emperor as the state head. After he realised the failure of his attempted coup d'état, Mishima committed a premodern ritual seppuku, suicide by disembowelment and beheading by his associate.

At the same time, however, he is considered as a homoerotic artist or 'gay writer' both outside of Japan and within the Japanese gay community ${ }^{1}$. Mishima published several 'gay' themed novels in the 1940s and 1950s, as well as his own homoerotic portrait photographs. His works attract interest by queer scholars and critics (Izumo, 2010; Saeki, 1997; Vincent, 2012; Watanabe, 1997). As Keith Vincent describes, Mishima Yukio is 'everyone's favorite homofascist' (Vincent, 2003: 1).

${ }^{1}$ I will review the arguments whether Mishima is a 'gay writer' or not later in this article. For fandom of Mishima Yukio as a gay icon among Japanese gay community in the 1970s, see Mackintosh (2012). 
Thus, Mishima has three faces: as a popular and representative writer in a post-war democratic and economically-expanding Japan, as an ultra-nationalist ideologue, and as one of the iconic writers and artists of homoeroticism, especially for homosexual audiences. Although some literary and cultural critiques focus on Mishima's sexuality for understanding his personality and works (Izumo, 2010; Piven, 2004; Vincent, 2012; Yamazaki, 1971), it is rare, if not at all, to discuss Mishima in the context of male same-sex politics in post-war Japan, for he is widely regarded as too nationalistic to be a gay pioneer. In this article, I regard Mishima as a distinctive artist who has offered a unique discourse, bridging a male homoerotic ethos with Japanese national politics through a trope of homoeroticising the emperor. This article aims to explore discursive relationships between Japanese national politics, homoeroticism, and homosexual politics through analysing Mishima's works and the published critiques of him. I will contextualise his discourse and politics into the history of male same-sex politics in Japan, rather than repeating previous research, which primarily focuses on his life, personality, and works, or contextualises him into a history of Japanese post-war -era politics and society (Miyoshi, 1991). Following Oguma Eiji's and Yumiko Iida's distinctive works on nationalism in post-war Japan, 'nationalism' here will refer to the political and emotional voices expressed through and for a nation, ethnicity, or the people (Oguma, 2002: 826; Iida, 2002: 2). The article will focus on how Mishima redefined Japanese national political domains through his commitment to the emperor system to include desire, gender expressions, and sexual passions, which were predominantly culturally excluded. Then, this article will argue how Mishima's adaptation of the emperor system as the homoerotic object has later influenced gei [gay] activism and development of gay studies, and demonstrates the limitation of Japanese contemporary queer national politics.

\section{MISHIMA YUKIO AND JAPANESE STEREOTYPES}

Mishima's performance as a modern 'samurai', the man who embodies the Japanese soul, who Mishima claimed post-war Japan had lost, succeeded in making people believe that he was one of few men who could represent true Japanese tradition and culture in post-war Japan. However, his exhibitionism as the authentic Japanese man has been criticised as strengthening Japanese stereotypes in the West, and some Japanese intellectuals have openly expressed their embarrassment about Mishima's embodiment of such an anachronistic Japanese stereotype for the West. For example, Kazuo Ishiguro and Ōe Kenzaburō, both now Nobel Laureates in Literature, agreed in conversation that his death was a performance directed primarily at Western audiences:

Ishiguro: $[\mathrm{M}] \mathrm{y}$ suspicion is that the image of Mishima in the West confirms certain stereotypical images of Japanese people for the West. And this is partly why I think he is much easier for Western audiences. He fits certain characteristics. Of course, committing seppuku is one of the clichés. He was politically very extreme. The problem is the whole image of Mishima in the West hasn't helped people there form an intelligent approach to Japanese culture and Japanese people. It has helped people perhaps to remain locked in certain prejudice and very superficial, stereotypical images of what Japanese people are like. (...)

Oe: The observations you just made about the reception of Mishima in Europe are accurate. Mishima's entire life, certainly including his death by suppuku, was a kind of performance designed to present the image of an archetypal Japanese. Moreover, the image was not the kind that arises spontaneously from a Japanese mentality. It was the superficial image of a Japanese as seen from a European point of view, a fantasy. Mishima acted out that image just as it was. (Shaffer et al., 2008: 55-56)

In this conversation, both writers openly expressed their discomfort and embarrassment with the fact that people outside of Japan, especially ones in the West, think of his performances as authentically Japanese. Ishiguro even goes as far as to suggest that such stereotypes reflected an ignorance toward Japanese culture.

In Off Center: Power and Culture Relations between Japan and the United States (1991), published just after the Showa period ended, Masao Miyoshi insisted that the Japanese people had lost interest in Mishima as a writer and instead tried to historicise Mishima in the context of post-war Japan, resisting the portrayal of Mishima as a legend. Miyoshi interpreted Mishima's aesthetics in relation to consumerism in post-war Japan, saying that 'much of Mishima Yukio's dazzling performance now looks merely flamboyant, or even kitschy' (Miyoshi, 1991: 149). Miyoshi's efforts to strip Mishima of his 'samurai' mask and to bind him to the past reflects typical Japanese intellectuals' trepidation for Western interpretations that 'misunderstand' Mishima as being authentically Japanese.

Miyoshi compares Mishima to other writers in the Showa age, such as Tanizaki Jun'Ichirō and Ōe, arguing that Mishima is writing from a centralist position of Japan. According to Miyoshi, Tanizaki's and Ōe's strategies were to place themselves as writers in a 'foreign' place, removed from the centre of Japan, in order to see Japan from distinctly off-centred perspectives. In contrast to them, Mishima was treated as just a fashionable man of his age, 
writing conventionally in order to claim authentic Japanese culture. In the USA, the 1960s were a time of dissent and conflict, questioning social hegemony, seeing the emergence of political activism and idealism such as the antiwar, civil rights and women's liberation movements and student protest. On the contrary, however, in the 1960s, Japan succeeded in expanding its economy. Japan's social struggles focused more on the question of whether, and how, Japan should be independent from the hegemony of the United States (Miyoshi, 1991: 156-7). Arguably, in this period, Japanese progressive intellectuals withdrew into their bourgeois daily lives after Japan's economic expansion; they became narrowly concerned with Japan's national independence from the United States, and the national pride that had been lost by the defeat in The Pacific War, (ibid:155). Miyoshi recalls that Mishima was a snob, but was a popular writer in the age of consumerism, who liked to talk about brands such as Tiffany and Jaeger and was proud of his iconoclastic Western house (even though he is remembered as the man who wanted to be a modern 'samurai' in Showa-era, who must be stoic) (ibid: 161-2). Miyoshi argues that Mishima's ideas on nationalism merely reflected the enthusiasm of a Japanese society endeavouring to recover nationalistic pride through economic recovery.

Even if Miyoshi were correct about Mishima's superficial consumerism (which is conventionally associated with femininity), Miyoshi still ignores Mishima's sexuality. At the time when Mishima enjoyed his public life, gay activism was not even imaginable for people in Japanese society. Although Miyoshi tries to represent Mishima synchronising with the 'orthodox' history of Japan, Mishima's sexuality produces excesses that cannot fit into such explanations. Mishima's sexuality is marked as an enigma, and a sign of his extremism. Mishima's sensational death and his sexuality — homosexuality and sadomasochism — are intertwined with a form of fetishistic nationalism.

\section{MISHIMA AND 'PERVERSION'}

Jerry S. Piven, an American psychologist writing about Mishima's 'perversion', insists that 'his life and writing are a palimpsest of early trauma, severe conflict, narcissistic injury, the obsession with death, sadomasochism, vengeance, and the terror of disintegration' (Piven, 1997: 2). His analysis reproduces the misogyny and homophobia that he finds in Mishima:

The elucidation of perverse sexualities thus entails tracing not only the obvious sadistic fantasies but also more elusive and unconscious rage and malice suffusing erotic desire. I believe that Mishima adopted and fantasized a number of perverse or neosexual strategies for coping with horrific terror and loss, including misogyny, the sexualization of violence, sadomasochistic fantasies, even his homosexual interactions, which in his case (not necessarily in other cases) implicate real emotional problems — as he often knew. [Emphasis in original] (ibid: 11)

Piven's rather clichéd analysis maintains that the problems of Mishima's ego were caused by the failure of proper gender identification in his childhood because of his weak father and his authoritarian grandmother: Mishima is a poor victim of the failure of his father's Oedipal Complex. He explains Mishima's personality through gender identifications: either via a hyper-identification with masculinity, an internalisation of femininity, or both. Firstly, he argues that Mishima identified with masculinity through the rejection of femininity, which, in his diagnosis, was especially symbolised by his grandmother (ibid: 44). One page later, however, he insists that Mishima also identified with 'perverse' women too. Thus, in his discussion, the homosexuality and sadomasochism of Mishima was always already perverse and the result of the failure of proper gender identifications, caused by destructive women, in this case, his grandmother. He constitutes the double bind of Mishima's homosexuality that Eve Kosofsky Sedgwick criticises: the gender separatist model or the gender inversion model (Sedgwick, 1990: 88). In Piven's explanations of Mishima's homosexuality, it was caused by misogyny, and his naked exhibitionism exceeded 'proper' masculinity.

With Mishima's scandalous death, in Vincent's words, 'Mishima became the writer that everyone loves to hate' (Vincent, 2003: 1). Ishiguro and Ōe, express worries over Mishima's 'misrepresentation' of the Japanese for the West. But such embarrassments belie a concern about the desire for recognition of the 'authentic' Japanese by the West. These discourses about sexuality, masculinity and authentic 'Japaneseness' well reflect Mishima's strategy to construct his image as the authentic Japanese man, even though all of such discourses invoke questions of 'realness' just as they are performed. Why does Mishima's masculinity and sexuality disquiet so many public figures? In the following discussion, I will analyse his ultra-nationalist political arguments rather than his personality, focusing on the relationships between Japanese politics, masculinity and homoeroticism. 


\section{THE EMPEROR AND HOMOEROTICISM IN MISHIMA'S POLITICAL THOUGHTS}

In his political essays, Mishima certainly links eroticism to political terrorism for the reconstruction of Japan, especially in his famous political essays The Defense of Culture [Bunka böei ron] (2006a) and The Manifesto of Antirevolution [Han-kakumei ron] (2006b), published in 1968 when left-leaning student activists were active and influential in Japanese society. His political thoughts need to be contextualised through key elements: Japan's historical uniqueness, the emperor, and homoeroticism.

According to Mishima, Japan is a unique country, which has had unusual historical continuity and cultural wholeness since its beginning as a nation. The Japanese, he insisted, must protect such continuities and prevent divisions and schisms in Japan:

Japan is a rare country in the world which is an ethnically homogeneous and unilingual one and our nation, which shares the language, culture and tradition, has kept political unity since the dawn of time. Thus, our cultural continuity is entirely dependent on the inseparability of the people from the state. (Mishima, 2006a: 60)

Such nostalgia for national 'purity' is of course a common fantasy of nationalisms. Mishima claimed that the left creates artificial conflicts between people within Japanese society:

Problems of Koreans and ethnic minorities in Japan, the left insists, are deceptive. (...) They already need to claim the problems of human alienation and alienation of ethnic minorities based on a fiction. Then, when they find alienation of one group, they will rush at it and only think to utilize it for a revolution. (Mishima, 2006b: 20-21)

Despite Mishima's asseveration, his idea of Japanese ethnical homogeneity since the beginning of Japanese history is rather mythical, if not self-deceiving. Although Mishima emphasises Japanese history for his polemic against the revolutionary left, he ignores the historical fact that Japan, the Empire of Japan, used to be a multiethnic state including Koreans, Taiwanese, and so on, despite post-war Japan relinquishing its territory due to its defeat of World War Two in 1945. ${ }^{2}$ Thus, Mishima - like nationalists everywhere - erases historical and social facts in order to promote myths of historical continuity and ethnic homogeneity in Japan.

Mishima's political purpose is to retrieve oneness between the Japanese ethnic people and the state through culture, not political institutions. What is distinctive about Mishima's concept of culture is that it embraces eroticism and disorder as essential elements. He argues that the concept of culture is in contraposition to the one of politics because politics supposedly exists to impose order whilst culture, such as poetry, exists creatively for the diversity of human life and activity. This means, he notes, that his idea of cultural wholeness is neither totalitarianism nor fascism repressing human freedom and controlling their behaviour. Rather, he insists, his idea of the emperor system radically accepts freedom of speech because it must include anything indiscriminately in its cultural space (and in that sense, he was a libertarian).

Mishima argued in favour of the emperor system of Japan which he construed as 'the emperor system as a cultural concept' (ibid: 66). He rewrites the character of the emperor since the Meiji Restoration, which reformed Japan as a modern state with the emperor as the monarch to maintain the political and social order in Japan. Mishima calls this reduced model 'the emperor as the political concept': "The emperor as the political concept had to sacrifice a great deal of the emperor as the cultural concept which is comprehensive and allows more freedom" (ibid: 75). This view of the emperor is both highly abstract and removed from the actual modern emperor system in Japan. Mishima insists that his political purpose is to make a coalition among the Japanese people under the emperor system as the cultural concept, which is even open to anarchism, in his view (ibid: 74). Despite such libertarianism, Mishima's extreme hostility against communists in Japan and his attempt at a coup d'état in the name of the emperor, belies his impulses to the contrary.

Mishima was fascinated by political battles under the name of the emperor and had created himself as a political agent through such battles. He claimed, as a romantic hero, that his position is the minority of the strong, the last guardian of Japanese culture, history, and tradition, intended to oppose the weak majority of the revolutionary thoughts in post-war Japan. When he opposes communism in The Manifesto of Anti-revolution [Han-kakumei sengen], due to the left's hostility against the emperor system and Hirohito himself, Mishima insists that their conflict must be a life-or-death battle, which can only happen once. In For Young Samurai [Wakaki samurai no tameni] (1969), published one year before his death, he regards the male body as a weapon: 'men's body must always be tense like the bow which is drawn toward a crisis' (Mishima, 1996: 29). Mishima ties together the Japanese male body, politics

${ }^{2}$ For the historical changes of discourses on who are 'the Japanese', see Oguma (2014). 
and culture aesthetically through a crisis. ${ }^{3}$ His politics evoke homoeroticism among men through the image of physical battles by well-trained, stereotypically beautiful men. His concept of culture-eroticism is destructive in nature, as Mishima was strongly influenced by Georges Bataille (Hirano, 1991). Thus, his political battle is supposed to be both homoerotic and (self)destructive, in love with death.

Homoeroticism functions at several levels in Mishima's political discourse. Firstly, erotic passion toward the emperor constitutes the foundation of his politics, which is destructive and combative and encourages selfsacrifice. Secondly, the homoeroticism of his politics defines the domain of politics, where only Japanese men are allowed to participate. ${ }^{4}$ Thirdly, his combative politics demands that Japanese men build up their bodies to use as attack against other men. Watanabe Mieko characterises his works as the paradise of death without women; he was obsessed with masculinity, death, male bodies, and the emperor (Watanabe, 1997). Mishima regarded the Japanese male body as being intrinsically political.

\section{MALE NUDITY, BLOOD, AND POLITICAL HOMOEROTICISM}

Mishima's highly symbolic use of a naked male body and blood amalgamates the celebration of masculinity for the nation and emperor with homoeroticism. Mishima directed the movie Yükoku [Patriotism] based on his same titled novel published in 1966, which was a highly sympathetic portrayal of the young officers involved in the coup d'état in the incident of February $26^{5}$. In the film, Mishima acted as the main character, a young officer who was ordered to crush the coup d'état organised by his best friends in the incident of February 26, and kills himself for dilemmas he experienced between justice and loyalty for friendship, the nation, and the emperor. Mishima explained his intentions about the film: "My main idea was to explore how Japanese Eros would fuse with death and under politically embattled circumstances, what the highest form of Eros would look like for justice or martyr" (Mishima, 2003a: 38). In the film's scene of seppuku, Mishima acted passionately, devoting five minutes of the 28minute movie to the scene of the officer's painful death. From the planning stage, this movie was produced for possible release outside Japan, as its style is stereotypical of Japan and is, thus, easily comprehended by Western audiences (ibid: 40). The movie starts with a scene in which the lieutenant tells his wife about his decision to commit ritual suicide by seppuku. He and his wife make love for the last time in front of a wall scroll, on which is written 'Shisei (allegiance)', and then comes the scene of their suicide: sacrificing themselves for the emperor and for the nation. In this sense, this movie is a part of Mishima's expression for his far-right thought and admiration of the pre-war loyalty for the emperor among Japanese military officers: an example of eroticisation and anesthetisation of fascism as Susan Sontag and Tanaka Jun point out in Mishima's works (Sontag, 1980; Tanaka, 2008).

The film critic and lesbian activist Izumo Marō (2015), highlighted the importance of Dōmoto Masaki's memoir published in 2005. Dōmoto was one of Mishima's closest friends and helped Mishima with stage effects in the movie production. According to Dōmoto, Patriotism, was also based on another novel anonymously written by Mishima, Ai no shokei [Execution of love] and published in the special issue for homosexual novels of an underground gay magazine Adonis (Izumo, 2010: 115-6, Dōmoto, 2005: 61-8). Ai no shokei was a homosexual pornographic novel fetishising seppuku in which a young, beautiful, and sadistic boy demands a masculine man to commit seppuku. The boy demanded seppuku as symbolism for the masculine man to prove his love for him. In his memoir, Dōmoto affirmed that he rewrote Mishima's handwriting transcript of 'Ai no shokę' ensuring anonymity (Dōmoto, 2005: 62, 65-6). Thus, the film can be interpreted as both an experimental film expressing Mishima's political thought and aesthetics made by Mishima himself and a queer film eroticising and fetishising seppuku. ${ }^{6}$

In the film, Mishima presented his body as a highly symbolic object. It is repeatedly shown either naked or uniformed; firstly, the lieutenant appears wearing his uniform, then he becomes fully naked for the sex scene. He wears his uniform again as part of the ritual suicide, with the help of his wife; he then becomes half-naked, opening his jacket for disembowelment. Finally, his wife puts his uniform back onto his dead body. His body is symbolised as the national through repeatedly changing between naked and uniformed.

In the scene where he commits seppuku in front of his wife, his body is objectified by his sword and his wife's gaze. During his ritual death, the viewer cannot see his facial expression because of the shadow of his hat, and the camera mainly focuses on his belly, though it sometimes gives a close-up of his mouth to indicate pain. When he stabs the base of his left leg to begin the seppuku and blood emerges from the wound, the camera focuses on his

\footnotetext{
${ }^{3}$ Mishima emphasised militant masculinity characterised by their muscled bodies in his introduction for a private militia, Tate-no-kai [the Shield Society] too. See Mishima (2003b: 721).

${ }^{4}$ Tanaka Jun points out that Mishima's theorisation of far-right terrorism evokes homoerotic bonds between Japanese men and the emperor through political anesthetisation rather than merely strengthening the emperor's authority (Tanaka, 2008: 250-258).

5 The February 26 incident was an attempted coup d'état, organised by a group of young Imperial Japanese Army Officers in 1936. It was considered to have put Japan on the path of militarism.

${ }^{6}$ For Mishima's 'seppuku fetishism and simulation play (seppuku shumi)' in private life, see Domoto (2005: 33-58).
} 
wife's face with her expression of shock at seeing his blood. After the stabbing and slitting of his belly, with its massive outpouring of blood, the camera switches to his face in pain, to her face, to his blood, to her face, then to his face. When the camera returns from the pained expression on his face to his belly, his intestines have come out. By these repeated shots, his blood and pain symbolise his loyalty to the emperor, and sanctified through the gaze of his wife, the only spectator. Even though she commits suicide after his death, this symbolises her love for him, not for the nation. She puts on makeup after his death, then commits suicide by slitting her neck with a knife. Her dead body nestles against his in the last scene.

In this film, the image of his blood is differentiated from that of hers. While the film's image of dark bright blood from his belly is realistic, the image of her blood is inversed, black and white reversed, so it appears as a white liquid splattered on the black wall. The images of blood in this film are gendered and differentiated through the classifications of love; one is love for a nation and the other is love for a person. This gendered expression of blood is inspired by the formation of gender roles in pre-war Japan: the male role is that of a warrior for the emperor, and the female role is that of a mother for men.

In the film, Mishima's expressions intertwine homoeroticism and nationalism - which is ambivalent, either he is expressing Japanese national ethos through homosocial desire and homoeroticism or homoeroticism in guise of Japanese nationalist manners. Therefore, Mishima's nationalist politics has been a controversial subject for gay critics $^{7}$. The obvious connection between homoeroticism and his ultra-nationalist politics provides his opponents with a reason to attack his sexuality. In the book Homosexuality and the Emperor System in Mishima Yukio [Mishima Yukio ni okeru nansyoku to Tenno-se]], published the year after Mishima died, Masao Yamazaki argued that Mishima's radical nationalist politics was caused by his sexuality, which failed to develop in the 'proper' way: into heterosexuality. Following Susan Sontag (1980), who pointed out the eroticisation of fascism in Mishima's works, Tanaka Jun (2008) also regards Mishima as the representative figure to explain the relationship between Japanese homosocial ties and fascist desires.

\section{QUEER CRITIQUE ON MISHIMA'S FASCIST AESTHETICS}

Mishima is probably one of the best known homoerotic artists in post-war Japan and also connected to farright politics. Gay Studies in Japan in their early stages had to analyse the connection between nationalist politics and homosexuality. Keith Vincent criticised Yamazaki's homophobic connection between homosexuality and nationalist politics in Gei Sutadiæu [Gay Studies] in Japan (Kawaguchi et al., 1997: 104-9, 139-140). Vincent tried to offer an alternative reading of the relationship between Mishima's fascist politics, homosexuality, and his ideal of being heterosexual in Japanese society (Vincent, 2003).

Izumo Marō recognises a historical fact that post-war society, which commonly joined homophobia with fascism, failed to liberate homosexuality and continued to repress it after fascism. Stressing such social contexts, she tries to interpret Mishima's works and performances as more than merely anachronistic works that express the close relationship between homoerotic desire and fascism. She writes: "What Mishima Yukio is, cannot fully be explained only by fascist aesthetics: his shocking self-images disseminate and then disappear into the ambiguity of mysticism" (Izumo, 2010:104). Izumo notes that it was the late 1970s when the critique of the alienation caused by sexuality and questions towards heterosexism emerged in the Japanese fourth estate. Before that, Izumo points out, representations of sexual minorities in underground culture, including drag queens and lesbians, were a part of a 'freak show', which existed outside of heteronormativity. Against such a social background, Izumo interprets, Mishima had spent his later life daringly exhibiting his male body as a spectacle. Izumo calls Mishima's performance of Japanese masculinity 'emotional right-wing kitsch' (ibid: 105). Izumo writes:

Looking back from the present of 2010 to the 1960s, Mishima's kitsch representation, which utilises a 'male body' determinately subjected to the norm belonging to the supreme man in politics and power, seems a challenge against the demands of explanation posed by heterosexism. Thus, I think, for queer gazes, what Mishima Yukio is to be deeply tied to the rhetoric of a blatantly openly secret like being in the glass closet. (ibid: 105)

In her interpretation, Mishima's aestheticisation of fascism is not the result of his homosexuality but rather the reappropriation of history and politics for expressing his sexuality in a homophobic society. Izumo focuses on the gay symbols in his film Yükoku and tries to read Mishima's performance as a self-expression of sexuality by a homosexual man in the closet in a homophobic society, rather than his yearning for fascism.

However, Izumo's conclusion is pessimistic about Mishima's efforts to express his desire and sexuality within social norms. She relates:

\footnotetext{
${ }^{7}$ As Dōmoto and Izumo emphasise, Mishima's works were intentionally written for homosexual audiences to enjoy as homosexual texts through queer reading and imagination which read female characters as men (Dōmoto, 2005: 82-3; Izumo, 2010: 115-6; Mackintosh, 2012).
} 
The alienation of sexuality is one of the important factors to understand Mishima's works. Mishima well acknowledged the structure of repression. That is the structure that when an alien raises questions, the questions are recognized as only aliens' problems, then excluded. Repressors never listen to aliens' crying. Mishima must have known such a nightmare.

It is the 1990s, twenty years after Mishima's suicide, that studies which question heteronormativity - the dualistic repressive structure which sets homosexuality against heterosexuality - are introduced and discussed in Japanese fourth estate. What Mishima attempted was the strategy to hide himself in his legend made by himself while accepting such a dualistic repressive structure. (ibid: 128)

Izumo regards his attempts to be doomed from the beginning because his body performances represent emptiness and signifies 'null'. She suggests that his fascination with death and attempt to be political, which was also hopelessly doomed, came from his emptiness, hiding his sexuality within the heteronormative norms as if it were 'a phantom in the ruins' (ibid: 128).

Although his attempt seems hopeless, do his discourses and performances really only signify his desperate expressions of his desire? It is notable that critics who emphasise the relationship between his sexuality and fascist politics contextualise him within history, while queer critics tend to liberate his expressions of sexuality through individualising them, focusing on his closeted sexuality. How can we best contextualise his expressions of sexuality in the Japanese history of male homosexuality?

\section{HISTORICISING MISHIMA YUKIO IN THE HISTORY OF HOMOSEXUALITY IN JAPAN}

In reading Mishima's works, a question has been repeatedly posed as to whether Mishima's novels, especially his representative work, Confessions of a Mask, published in 1949, can be called the first 'gay' literature in Japan and whether it expresses gayness in the sense of Westernised sexual identity or not.

Saeki Junko (1997) insists that we cannot identify the same-sex desire of ' $\mathrm{I}$ ' in Confession of a Mask as 'homosexuality' in the modern Western sense, because she finds traditional forms of same-sex sexual relations such as existed in pre-modern Japan in his narrative, including his attraction to men of a different age group from his own. But she also argues that ' $\mathrm{I}$ ' is influenced by 'Western prejudices' about male love, as 'I' considers his samesex desires sinful and shameful, compared to traditionally tolerant Japanese attitudes towards same-sex sexual conduct in pre-modern Japan. She therefore concludes that the character ' $\mathrm{T}$ ' in Confession of a Mask represents the mixed characteristics of indigenous and exogenous elements of male love in modernised Japan.

Keith Vincent maintains that 'homosexuality' in Confession of a Mask is not understood as an identity but, rather, echoes what he calls 'homosocial narrative', which is the early modern Japanese narrative of same-sex desire that regards same-sex sexuality as 'a developmental stage belonging to adolescence that would eventually and inevitably give way to heterosexuality in adulthood' (Vincent, 2012: 178). This is the opposite to the critic Atogami Shiro, who insists that Confession of a Mask is the 'dawn of modernity in homosexual literature' expressing same-sex desire as one's sexual orientation (ibid: 175). Vincent notes the movements of desire in a narrative rather than a fixed identity based on sexual desire, while admitting the possibility that Confession of a Mask can be retroactively interpreted as a 'homosexual novel'. Thus, Vincent's conclusion is closer to Saeki's. It expresses not both traditional homosexual narratives and new identity-oriented same-sex desire, but neither of them. 'In my reading', Vincent writes, 'Mishima's novel is neither a piece of "homosexual literature" nor a homosocial narrative, but a text that hovers uncomfortably in between' (ibid: 175.).

It is noteworthy that the critiques which focus on sexual minorities in modern Japan are divided over whether Mishima's novel belongs to traditional Japanese sexuality or indicates the dawn of a Westernised sexual identity, or whether it belongs to both of them or neither of them. However, the coexistence of opposing discourses rather suggests that the question that they both rely on is not a proper one in analysing Mishima's works, as both of them only produce their interpretations but fail to contextualise the works, even though they have tried to. Nevertheless, what is notable in the coexistence of opposing discourses is the fact that Saeki and Vincent insist on the opposing conclusions but stand on common ground that Mishima's work includes something different about same-sex sexuality in Japan, alienating itself from the past and from contemporary Japan.

Here, instead of asking the question - the question non-Western cultures are almost always forced to answer of whether Mishima belongs to 'traditional' Japanese sexuality or to the dawn of a 'Westernised' sexual identity, I will focus on contextualising Mishima's discourses in the history of same-sex sexuality in Japan and on clarifying the features of Mishima that still have an influence on ideas of same-sex sexuality in Japan. Although Mishima became a popular writer by producing works about homosexuality, in later years he did not write 'homosexual' novels anymore. However, his later works still retained elements of homoeroticism, and those have often been 
linked to his far-right politics. What is notable in Mishima is not his homoerotic expression itself, but his change of style of homoerotic expression. Thus, one question we need to ask is: what is the difference between his early style and later style of homoeroticism?

Contextualising Mishima's works, Sabine Frühstück (2003) and Gregory M. Pflugfelder (2007) have already shown that Western medical discourses on sexuality were translated into Japanese in the early stages of Japan's modernisation. As early as 1890, the conduct of 'homosexuality' was beginning to be formulated through translations of Western medical concepts, and people's sexuality was considered a subject that society had to deal with in Japan. As 'homosexuality' was already standardised as 'same-sex love (doseial)' by the 1920s, and homosexuals and 'pervert' characters were often represented in popular culture after the 1920s, it is reasonable to suppose that Mishima, who was familiar with Western classical culture, was well acquainted with homosexuality in the modern Western sense when he wrote Confession of a Mask. Thus, it is rather anachronistic and misleading to focus on the question of whether he expresses the sexual identity familiar to homosexuals, or 'gay' identity in contemporary society, or whether he expresses 'traditional' Japanese sexuality.

His second homosexuality-themed novel published in 1951, Forbidden Colors, also echoes pre-war expressions of homosexuality: ero-guro-nansensu. Pflugfelder characterises the discourses about homosexuality in ero-guro-nansensu as demonstrating three elements: firstly, 'same-sex love' was linked with a vaguely 'grotesque' urban environment at the time when cities such as Tokyo and Osaka were rapidly growing in Japan and new subcultures of male-male eroticism were emerging in the large cities; secondly, prostitutes were frequently portrayed as central actors in this subculture, embodying an 'inverted' trope of male-male sexual behaviour; thirdly, same-sex love is represented conceptually as having a close relationship with criminality (Pflugfelder, 2007: 310-311). Even though it is a heavy work of literature, rather than popular novels as ero-guro-nansensu were, Forbidden Colors, which portrays the underground culture of homosexuals in Tokyo in the early 1950s, clearly takes over the characteristics of the genre of ero-guro-nansensu. ${ }^{8}$

As Mishima turned from being a 'homosexual' writer to being a far-right activist, the expression and meaning of same-sex desire in his work also changed. In his early works, same-sex desire is expressed as being disturbing for the men who hold it; it is a shameful desire, or a desire isolating men from society. In his later works, however, homoerotic desire is not shameful but rather an essential desire to participate in national politics. As Mishima's homoerotic desire functions as an expression of loyalty to the emperor and identification with war heroes who also were loyal to the emperor, homoeroticism, or a desire for strong male bonds, represents national politics, masculinity and a nation-state itself. In his discourse, homoeroticism builds a mutually complementary relationship with Japanese national politics. Now, homoerotic desire is something essential in a nation-state.

Certainly, representations of cultural and political homoeroticism existed in pre-war Japan before Mishima (Pflugfelder, 2007; Reichert, 2006). However, those representations used to be regarded as something negative, temporarily indicating the past, of pre-modern federal Japan or excess of modernisation (Kawasaka, 2018; Vincent, 2012). In Mishima's discourse, on the other hand, homoerotic desire has become something central in Japanese politics, relating the present, or the living tradition. In his redefinition of the emperor system for his politics, Mishima succeeded in involving homoeroticism, or something very close to homosexuality, in national politics, and in explicitly recontextualising it from Japanese tradition to contemporary Japan. Retrospectively, it is a politically distinctive moment for homosexual politics in Japan, as same-sex desire is now regarded as something not outside of contemporary Japanese society, either the past or the West, nor something in underground cultures but central. He redefined it as a political desire that allows Japanese men to access the emperor.

Ironically, Mishima's political discourses, which constructed close relationships between the emperor and homoeroticism, was reappropriated and succeeded by a far left sexual dissident activist in the 1970s, after Mishima's death, but in this case mobilised against the emperor. Togo Ken (1932-2012), a pioneer of gay activism in Japan, challenged the emperor's political holiness by grotesquely homoeroticising him. Although Mishima reformulated same-sex desire as something denoting loyalty and national unity, Togo insisted that Japanese society regarded same-sex desire as inferior (Togo, 1979: 152). He utilised it against morals, norms and the emperor by expressing his same-sex desire and identity openly (McLelland, 2005; 2012). Togo's political purpose is the opposite of Mishima's but the latter's discourse of same-sex desire, which admits it into the national political domain, enabled Togo to promote his desire as a political issue in Japanese society.

\section{THE EMPEROR SYSTEM AS THE LIMITATION OF QUEER POLITICS IN JAPAN}

The contextualisation of Mishima's ultranationalist political discourses into Japanese politics appear to be repeating already well-discussed topics of 'homofascism' in Sexuality Studies: how essential homoeroticism has been in fascist aesthetics and ideology (Champagne, 2013; Mosse, 1985; Tanaka, 2008). On the other hand,

${ }^{8}$ For representations of homosexuality in ero-guro-nansensu, see also Kuroiwa (2013). 
connections between fascism and homosexuality have been criticised as potentially a part of political obsessions which distort homosexuality and attach it to unfavourable political radicalisms - either far-left or far-right movements such as McCarthyism and Frankfurt School's analysis of 'authoritarian personality' (Halle, 1995; Hewitt, 1996; Johnson, 2004). Rather than discussing Mishima in relation to these issues as Vincent (2003) has, I argue that the emperor system has been essential for sexual politics in post-war Japan and must not be ignored by queer politics, even now. Mishima's homoerotic nationalist discourse and performance indicate an under-argued political-emotional function of the emperor in Japan: the emperor system in Japan is not only the ideological grounding of the heteronormative family system, but also can embrace male homoerotic ethos and prepare a cultural circuit for Japanese male sexual minorities into Japanese nationalism.

Traditionally, Japan's emperor system has been regarded as the political institution to sustain the Japanese patriarchal heteronormative family system (Maree, 2014). When Maruyama Masao, a representative political philosopher in post-war Japan, reflected on Japanese wartime fascism in 1946, he argued that Japanese fascist ideology was differentiated from Italian fascism and Nazism. According to Maruyama, one of its characteristics was 'familism [Karoku shugi]' which represented the nation as a big family with the emperor as the symbolic patriarchal head and Japanese ethnic citizens as his children (Maruyama, 1964: 42). Through Japanese familism as a fascist ideology, Maruyama insists, Japanese ethnic people were actually imagined as the consanguineous group, not a metaphoric family, which helped to form a strong Japanese national identity differentiated from the West and other Asians (Maruyama, 1964: 42-3). Even in contemporary Japan, the emperor system is utilised to cement Japanese national identity along with 'traditional' family values, sustaining Japanese institutionalised sexism and xenophobia. For example, in the 2000s, the conservative backlash movements grew against feminism, sexual education, issues of war sexual slavery [ianfu], and gender equality policies. Their campaigns collaborated well with powerful politicians such as Abe Shinzō, have often exploited homophobia and transphobia, and called for protecting the 'traditional' family values and the emperor system. They employed disinformation in a conspiracist manner, with feminists promoting communism that would abolish Japan's emperor system (Soku, 2016; Wakakuwa et al., 2011).

The double-binding representations of the emperor system - the source of heteronormative family values and the fetish object of homoerotic admiration by Mishima's followers - have influenced the development of Japanese gay activism and gay studies, especially after the AIDS crisis which was represented as a threat to Japanese society from homosexuals and foreigners (Treat, 1999). To avoid Japanese nationalism and homogeneity, gay activism such as OCCUR (Ugoku Gei to Rezubian no Kai [Group of acting gays and lesbians]) employed identity politics for their strategy (McLelland, 2005) and gay scholars, such as Kawaguchi Kazuya, Kazama Takashi, and Keith Vincent, adopted Eve K. Sedgwick's 'queer reading' as a method to read hidden homophobia in Japanese society, not queer desires as Sedgwick (1990) originally practised (Kawaguchi et al., 1997). For the emperor system can both be the institutional guarantee of heteronormative family values and embrace male homoerotic ethos, it cannot be a threat against Japanese political and sexual normativity to expose hidden queer and homoerotic desires among Japanese men. Rather, these exposures can be utilised against queer activists' claims about Japanese discrimination and repression against sexual minorities.

Criticism against the emperor system still can be treated as a taboo in LGBT activisms in Japan as well. In May 2018, Tokyo Rainbow Pride was targeted by the conservative online media and Twitter users as the pictures showed some participates holding placards with political messages such as 'Resign, (Prime Minister) Abe' and 'Crush the Emperor System [kutabare tennö-see]' (News Vision, 2018). A gay writer also criticised these messages as 'LGBT activists exploit the "weak" for their political purpose' (Jack, 2018, 45). What is noticeable in this phenomenon is that criticism against the emperor system can bring together the gay community and the conservatives against LGBT rights, and limits what queer movements can politically speak out about in Japanese society. The emperor system is a part of Japanese political institutions which sustain heterosexism and marginalise queer lives, but there is a strong social pressure not to criticise this, even within LGBT community.

Mishima Yukio offered a new homoerotic far-right discourse and redefined the emperor system as the homoerotic object which can theoretically embrace Japanese male homosexuals. His redefinition of the emperor system may be seductive for some Japanese male homosexuals as it offers a membership of the nation through their desire, without changing political institutions and culture. At the same time, however, it politically limits the possibilities of queer activism and even contributes to repress social minorities' inclusion in the Japanese imaginary.

\section{CONCLUSION}

Mishima's nationalist discourses have made space for male same-sex desire in Japanese public culture and national politics. His ideas about the emperor system radically embrace male homoerotic ethos and has prepared a cultural path for Japanese male sexual minorities into Japanese nationalism. In this sense, he is one of the first celebrities to change the concept of the relationship between male same-sex desire and contemporary national 
politics in modern Japan. He shaped a new form of discourse on male same-sex desire, differentiated from the previous and concurrent medical discourses or the ero-guro-nansensu discourses, both of which marginalised homosexuals. Mishima, we can say, has broken new political ground for male sexuality in post-war Japan.

Unfortunately, his discourses still define the contemporary Japanese queer political environment in a negative way. Mishima expanded the figure of the emperor for Japanese male homosexuals to be included within Japanese ethnonationalism. At the same time, however, his discourses enclose them within Japanese national norms and identity, obstructing transnational/cultural solidarity and political cooperation with feminists as well.

Some critics of Mishima tend to treat his sexuality and personal desire as the source of his far-right politics and extremism. These criticisms, which alienate Mishima's 'homofascism' with implicit homophobia, only serve to naturalise and enforce heteronormativity based on the Japanese emperor system. I suggest that it is more fruitful to understand Mishima's nationalist homoeroticism as a product of the emperor system at the centre of people's desire and admiration, in post-war Japan. The relations between the emperor and socially marginalised people, promote dynamics of inclusion and exclusion of social members through Japanese ethnonationalism. But at the same time, such dynamism itself is a product of social hierarchy based on the emperor system and predefines and restricts minorities' lives. Mishima prepared the new political ground for Japanese male homosexuals but it means he invited and confined them to such political dynamism by the emperor system as if it is the safest and happiest place.

\section{REFERENCES}

Champagne, J. (2013). Aesthetic Modernism and Masculinity in Fascist Italy. London and New York: Routledge.

Dōmoto, M. (2005). Kaiso: kaiten-tobira no Mishima Yukio [Memories: Mishima Yukio on a pivoted door]. Tokyo: Bungeishunjū.

Frühstück, S. (2003). Colonizing Sex: Sexology and Social Control in Modern Japan. Berkeley: University of California Press.

Halle, R. (1995). Between Marxism and Psychoanalysis: Antifascism and Antihomosexuality in the Frankfurt School. Journal of Homoexuality. 29(4), 295-317. https://doi.org/10.1300/J082v29n04_02

Hirano, Y. (1991). Mishima Yukio to G. Battaille: kindai sakke to seiou [Mishima Yukio and G. Battaille: The Modern Writer and the West]. Tokyo: Kaibunsya Shuppan.

Iida, Y. (2002). Rethinking Identity in Modern Japan: Nationalism as Aesthetics. London and New York: Routledge.

Izumo, M. (2010). Desupareto na sonzai keitai: danyu Mishima Yukio shiron [A Desparate Man: An Attempt at Interpretation of Actor Mishima Yukio], in Kurosawa, K., Yomota, I., Yoshimi, S., Lee, B. (eds), Kantoku to haiju no bigaku [Aesthetics of directors and actors] (pp. 103-131), Tokyo: Iwanami Shoten.

Jack, K. (2018). LGBT bijinesu no futsugō na shinjitsu [Inconvenient truth of LGBT business], Shukan Shincho, 42-45.

Johnson, D. K. (2004). The Lavender Scare: The Cold War Persecutions of Gays and Lesbians in the Federal Government. Chicago: The University of Chicago Press.

Kawaguchi, K., Kazama, T. and Vincent, K. (1997). Gei Sutadiæu. Tokyo: Seidosha.

Kawasaka, K. (2018). Contradictory Discourses on Sexual Normality and National Identity in Japanese Modernity. Sexuality \& Culture, 22(2), 593-613. https://doi.org/10.1007/s12119-017-9485-z

Keen, D. (2006). Mishima Yukio, in de Bary, W. T., Gluck, C. and Tiedemann, A. E. (eds.) Sources of Japanese Tradition, Abridged Part 2: 1868 to 2000 Second Edition (pp. 462-464). New York: Colombia University Press.

Kuroiwa, Y. (2013). Ero-guro-nansensu to sei [ero-guro-nansensu and sexuality]. in Nitta, K. (ed), Jenda kenkyu no genzai [Contemporary Gender Studies] (pp. 143-160). Tokyo: Rikkyo Daigaku Shuppan.

Mackintosh, J. (2012). The Homo Culture of Iconic Personality in Early-to-Mid Postwar Japan: Mishima Yukio and Misora Hibari, in J. Galbraith and J. Karlin (eds), Idols and Celebrity in Japanese Media Culture (pp. 131-152). London: Palgrave. https://doi.org/10.1057/9781137283788_7

Maree, C. (2014) Sexual citizenship at the intersections of patriarchy and heteronormativity Same-sex partnerships and the koseki, in D. Chapman and K. J. Krogness (eds), Japan's Household Registration System and Citizenship: Koseki, Identification and Documentation (p.p. 187-202). London and New York: Routledge.

Maruyama, M. (1964). Cho-kokka shugi no ronri to shinri [The Logic and Psychology of Ultranationalism]. Tokyo: Mirai-sha.

McLelland, M. (2005). Queer Japan from the Pacific War to the Internet age. Lanham: Rowman \& Littlefield Publishers.

McLelland, M. J. (2012). Death of the 'Legendary Okama' Togo Ken: challenging commonsense lifestyles in postwar Japan'. Pacific Journal: Japan Focus. 10 (25). June 18.

Mishima, Y. (2003a). Seisaku no ito oyobi keika [notes for the production], in Mishima Yukio Zenshu, Vol. 35 (pp. 35-64). Tokyo: Shinchosha. 
Mishima, Y. (2003b). 'Tate-no-kai' no koto [On Tate-no-kai], in Mishima Yukio Zenshu Vol. 35 (pp. 720-727). Tokyo: Shinchosha.

Mishima, Y. (1996). Wakaki samurai no tameni [For youthful samurai]. Tokyo: Bunshun Bunko.

Mishima, Y. (2006a). Bunka bōeiron [The Defense of Culture], in Bunka Bōeiron (pp. 33-86). Tokyo: Chikuma Bunko.

Mishima, Y. (2006b). Han-kakumei sengen [The Manifesto of Anti-revolution], in Bunka böeiron (pp. 9-31). Tokyo: Chikuma Bunko.

Miyoshi, M. (1991). Off Center: Power and Culture Relations between Japan and the United States. Cambridge: Harvard University Press.

Mosse, G. (1985). Nationalism and Sexuality: Middle-Class Morality and Sexual Norms in Modern Europe. The University of Wisconsin Press, London.

News Vision. (2018). LGBT wa naze seijiriyō sareru noka? Parēdo de tobikatta purakādo no mukōgawa [Why are LGBT people politically utilized? The truth behind the placards]. News Vision. Available at: https://newsvision.jp/article/188305 (Accessed 1 August 2018)

Oguma, E. (2002). 'Minshü' to 'aikoku': sengo nihon no nahonarizumu to koukyo-sei ['The People' and 'Patriotism': Nationalism and the Public in PostWar Japan]. Tokyo: Shin'yo-Sha.

Oguma, E. (2014). The Boundaries of 'The Japanese': Okinawa 1818-1972 Inclusion and Exclusion. Strickland, L. R. (trans). Melbourne: Trans Pacific Press.

Pflugfelder, G. M. (2007). Cartographies of Desire: Male-Male Sexuality in Japanese Discourse 1600-1950. Berkley: University of California Press.

Piven, J. S. (2004). The Madness and Perversion of Yukio Mishima, London: Praeger.

Reichert, J. (2006). In the Company of Men: Representations of Male-Male. Sexuality in Meiji Literature. Stanford: Stanford University Press.

Saeki, J. (1997). From Nanshoku to Homosexuality: A Comparative Study of Mishima Yukio's Confession of a Mask. Japan Review, 8, 127-142.

Sedgwick, E. K. (1990). The Epistemology of Closet. Berkley: University of California Press.

Shaffer, B. W. and Wong, C. W. (eds). (2008). Conversations with Kaquo Ishiguro. Mississippi: University Press of Mississippi.

Soku, H. (2016). Jenda bakkurashu toha nani data noka? [What were the Gender Backlash Movements?]. Tokyo: Inpakuto shuppan kai.

Sontag, S. (1980). Fascinating Fascism, in Under the Sign of Saturn (pp. 73-105). New York: Farrar Strauss.

Tanaka, J. (2008). Seiji no bigaku: kenryoku to byousho [Aesthetics of politics: Power and Representation]. Tokyo: University of Tokyo Press.

Togo, K. (1979). Zatsumin no ronri [logic of people]. Tokyo: Epona shuppan.

Treat, J. W. (1999). Great Mirrors Shattered: Homosexuality, Orientalism, and Japan. New York and Oxford: Oxford University Press.

Vincent, K. (2003). Mishima Yukio: Everyone's Favorite Homofascist, Multitude (13) Été. Available at: http:/ / www.multitudes.net/mishima-yukio-everyone-s-favorite (Accessed 1 August 2018)

Vincent, K. (2012). Two-Timing Modernity: Homosocial Narrative in Modern Japanese Fiction. Cambridge: Harvard University Press. https://doi.org/10.2307/j.ctt1x07z26

Wakakuwa, M. and Fujimura-Fanselow, K. (2011). Backlash Against Gender Equality after 2000, in FujimuraFanselow, K. (ed.) Transforming Japan: How Feminism and Diversity are Making a Difference (pp. 337-359). New York: The Feminist Press.

Watanabe, M. (1997). Onna no inai shi no rakuen: Kugi no shintail Mishima Yukio [The Paradise of Death without Women: Body of Sacrifice/Mishima Yukio]. Tokyo: Gendai Shokan.

Yamazaki, M. (1971). Mishima Yukio ni okeru nansyoku to Tenno-sei [Homosexuality and Emperor System of Mishima Yukio]. Tokyo: Kaien-shobo.

Citation: Kawasaka, K. (2018). Mishima Yukio and the Homoeroticisation of the Emperor of Japan. Feminist Encounters: A Journal of Critical Studies in Culture and Politics, 2(2), 23. https://doi.org/10.20897/femenc/3891

Copyright (C) 2018 by Author/s and Licensed by Lectito BV, Netherlands. This is an open access article distributed under the Creative Commons Attribution License which permits unrestricted use, distribution, and reproduction in any medium, provided the original work is properly cited. 